De Jure: Jurnal Hukum dan Syari’ah

Vol. 10, No. 1, 2018, h. 12-20

ISSN (Print): 2085-1618, ISSN (Online): 2528-1658

DOI: http://dx.doi.org/10.18860/j-fsh.v10i1.6466

Available online at http://ejournal.uin-malang.ac.id/index.php/syariah

\title{
The Provision of Radd in Inheritance Between Islamic Jurisprudence and the Algerian Family Law
}

\author{
Maiza Aissa \\ Faculty of Law and Political Science University of Djelfa, Algeria \\ aissa_al@yahoo.fr
}

\begin{abstract}
:
This study is aimed to figure out on how current legal device gives legal certainty over the excess of heritage partition $(r a d d)$ in Algeria. The comparation between Islamic jurisprudence and the Algerian Family Law is used to analyse judicial consideration on which matters regarding the excess of heritage partition are based. The writer used normative law method which consists of statute approach and conceptual approach. The understanding of radd in Islamic scholars' views differ from one another. Some scholars accept the concept and some do not. Those who disagree with radd consider that the excess of heritage should be given to bayt al mal as muslims representative. On the other hand, scholars who agree with the concept of radd have also different opinions regarding who are entitled to receive the excess of heritage. Some include spouse (husband or wife) but some exclude him/her. The Algerian Family Law gives provision in this case for a legal certanty, as it's stated in the article number 167 of the Algerian Family Code that wife and husband are excluded to receive radd. They can only receive it in the absence of ashaba heirs/residuaries, other fixed share heirs, and dzaw al arham (uterine relatives).
\end{abstract}

Penelitian ini bertujuan untuk mengetahui bagaimana perangkat hukum saat ini memberikan kepastian hukum atas kelebihan bagian warisan (radd) di Aljazair. Penelitian ini menggunakan pendekatan perbandingan antara fikih Islam dan Hukum Keluarga Aljazair. Penulis menggunakan metode hukum normatif yang terdiri dari pendekatan perundang-undangan dan pendekatan konseptual. Pemahaman radd dalam pandangan sarjana Islam berbeda satu sama lain. Beberapa sarjana menerima konsep itu dan beberapa tidak. Mereka yang tidak setuju dengan radd menganggap bahwa kelebihan warisan harus diberikan kepada bayt al mal sebagai perwakilan muslim. Di sisi lain, para sarjana yang setuju dengan konsep radd juga memiliki pendapat berbeda tentang siapa yang berhak menerima kelebihan warisan. Hukum Keluarga Aljazair memberikan ketentuan dalam kasus ini untuk kepastian hukum, seperti yang dinyatakan dalam pasal 167 dari Kode Keluarga Aljazair bahwa istri dan suami dikecualikan untuk menerima radd. Mereka hanya dapat menerimanya tanpa adanya ahli waris/ashabah, pewaris bagian tetap lainnya, dan dzaw al arham (kerabat dekat).

Keywords: inheritance; radd; algeria 


\section{Introduction}

The study of inheritance takes a great place and has an independent chapter in the Islamic Jurisprudence or Figh ${ }^{1}$ The Islamic jurists gives it special attention due to the existence of its detailed provisions stated by God Almighty in the holy Quran. As it explained in Qur'an surah al-Nisa' verses 11, 12 and 176 concerning the portions of inheritance for some heirs. It's also mentioned in the same Surah verses 13 and 14 about the reward to those who obey this rules to enter His heaven and the punishment to enter hell for those who disobey. The importance of this knowledge is also undeniable as the prophet insist to learn and teach it. Some of the jurists in Islamic inheritance considered it as one third of science through al hadith narrated by Abdullah ibn' Amr ibn al-'Aas that the messenger of Allah (peace and blessings of Allah be upon him) said: "Knowledge has three categories; anything else is extra; a precise verse, or an established sunnah (practice), or a firm obligatory duty ${ }^{2}$. While most Islamic scholars considered it as half of science that the Messenger of Allah said:" O Abu Hurairah. Learn about the inheritance and teach it, for it is half of knowledge, but it will be forgotten. This is the first thing that will be taken away from my nation".3

In addition, the Islamic jurists distinguished it with other knowledge by giving further detailed explanation of the heirs entitled to the property or inheritance on one's death, their legacy portions, and the methods of legacy distribution among them. Besides, they wrote many books, prose and main texts related to it and one of their most famous works is "Rahbiya"4. It's perceived that study of inheritance in Islamic jurisprudence tends to be normative and taken for granted. For instance, the legacy portion of men is twice bigger than that of women except father and mother of the deceased. In the 21th century, the study of inheritance in Islamic Jurisprudence still get great attention from Islamic scholars eventhough some thoughts about inheritance emphasize more about gender, rights of women in property sharing and claims that property sharing of women in Islamic inheritance is not equal to men. ${ }^{5}$ In some countries with most muslims as citizens especially in Middle East and North Africa (MENA) including Algeria, Islamic notions concerning rights of inheritance are incorporated into their family law codes regulating personal status laws. ${ }^{6}$

\footnotetext{
${ }^{1}$ Wahbah al-Zuhaili, Al fiqh al islami wa adillatuh, vol. 10 (Beirut: Dar al-Fikr, 2006), 7695.

2 Abi Dawud Sulaiman bin al asy'ath al Sajastany, Sunan Aby Dawud (Riyadh: Maktabah al Ma'arif li al Nasyr wa al Tawzi', t.t.), 513.

${ }^{3}$ Aby Abdillah Muhammad bin Yazid al Qazwiny, Sunan Ibn Majah (Riyadh: Maktabah al Ma'arif li al Nasyr wa al Tawzi', t.t.), 462.

4 Al-Rahbiya an Educational Poetry about the rules of inheritance (Fara'id) Written by Imam Abu Abdullah Mohammed bin Ali bin Mohammed Rahbi according the town of Rahba in Bilad al-Sham Middle east-, Consists of 176 lines, He took the doctrine of Zeid ibn Thabit in his work cause of the testimony of our messenger where he said: "... and the most knowledgeable of the rules of inheritance (Fara'id) is Zaid bin Thabit....."

${ }^{5}$ Issa Khan dkk., "The right of women in property sharing in Bangladesh: Can the islamic inheritance system eliminate discrimination?," SpringerPlus 5, no. 1 (3 Oktober 2016): 1, https://doi.org/10.1186/s40064-016-3347-2.

${ }^{6}$ Dörthe Engelcke, "Family Law Reform in Algeria: National Politics, Key Actors, and Transnational Factors," dalam Women and Social Change in North Africa, ed. oleh Doris H. Gray dan Nadia Sonneveld, 1 ed. (Cambridge University Press, 2018), 308, https://doi.org/10.1017/9781108303415.015.
} 
Eventhough the shares of the primary heirs are explained in detail in the Qur'an, there are still many problems that need to be resolved and there are many differences regarding how to solve them, especially because the Qur'an only explains basic problems. So that when certain problems arose and had no definite provisions in the Quran, the jurists, including the companions of the Prophet, tried to find a way out through ijtihad (independent reason) based on the Qur'an and Hadith which finally sparks some differences of opinions. One of the problems is about radd/return. $R a d d /$ return is an excess share or residual heritage. If nobody is alive to take balance share after the fixed share is given to the fixed heirs, and there is still balance left, then it is called as excess share and is returned to the people with fixed share (fixed heirs) ${ }^{7}$ The problem concerning radd arise as most of Islamic scholars exclude spouse, husband or wife, to receive the excess share. The spouse is excluded to get the return on reason that he/she has no blood relation to the deceased. Meanwhile, when the calculated shares of heirs are increased from the supposed shares, the supposed shares are increased to match the number of the calculated shares. In this manner, the actual amount/quantity of all fixed heirs including husband or wife is reduced. This doctrine is called Aul principle. ${ }^{8}$ This condition, off course, raises diferences of thought among scholars mainly because the spouse is excluded to get additional share through radd, while in case of 'aul, he/she will also get share reduction together with other heirs in the distribution of inheriatance. The study argues that Algerian legislators incorporates radd principle into their family law code differently from the opinion of most Islamic scholars.

\section{Method}

This study is a normative comparative research which consists of statute and conceptual approaches. The comparation is used to analyse judicial consideration on which the excess of heritage partition $(\mathrm{radd})$ are based, both from Islamic Jurisprudence and The Algerian Family Law. The Primary data are collected from books of Islamic Jurisprudence addressing radd system and the Algerian Family Law Code. Those data are also supported by secondary ones such as journal articles and books related to the reseach topic.

\section{Finding and Result}

\section{The provision of Radd in Islamic Jurisprudence}

Radd is an Excess share. If nobody is alive to take balance share after the fixed share is given to the heirs, and there is still balance left, then it is called as excess share and is returned to the people with fixed share (fixed heirs). ${ }^{9}$ Radd can't be found in the issue of inheritance without the existence of the three conditions; 1) the excess of heritage after being given to the fixed heirs. 2) the existence of a fixed heir. 3) no ashaba heir who inherits by taking the rest of heritage after being given to the fixed heirs. The provision of radd in Islamic Sharia differs into two main doctrines. The first

\footnotetext{
${ }^{7}$ Muhammad Ali Al Shabuni, Al-Mawarith fi al-Shari'ah al-Islamiah fi Daw'i al-Kitabwa al-Sunnah (Egypt: Dar al-Hadith, t.t.), 123.

${ }^{8}$ Asaf A. A. Fyzee, Outlines Of Muhammadan Law, 3 ed. (New Delhi: Oxford University Press, 1948), 331, http://archive.org/details/in.ernet.dli.2015.461646.

${ }^{9}$ Al Shabuni, Al-Mawarith fi al-Shari'ah al-Islamiah, 123.
} 
doctrine is stated by Zayd ibn Thabit, Imam Malik and Shafei, Al-Auza'i, Daoud Al Dhahiri who opposed radd theory. According to them, the rest of heritage, in case of no ashaba heir, is given to Bayt al-mal ${ }^{10}$ and there is no return from the rest of heritage to the fixed share heirs.

The Second doctrine is the utterance of Omar, Ali, ibn 'Abbas, Abdullah bin Mas'ud, the doctrine of Imam Ahmad, Abu Hanifa and their companions, the adherents of Maaliki school and Shaafe'i school who support radd theory. According to them, if there is still balance after being distributed to the fixed heirs whereas no ashabah heir, the rest of heritage is returned to the fixed heirs by percentage of their fixed shares. ${ }^{11}$ In addition, Shafe'i school support radd on condition that Bayt al-mal is not functioning properly otherwise the rest of heritage must be returned to Bayt al-mal. 'Omar, Ali and most of Islamic scholars give the return from the excess of heritage to all fixed heirs except Husband and wife. According to them, the return (radd) is only given to the fixed heirs who have uterine relationship with the deceased. So, those who have only relation to the deceased through marital relation are unable to receive the return. ${ }^{12}$

'Othman ibn Affan, in this case, give the return to all fixed heirs without exception including husband (widower) and wife (widow). He based his argument on rational thought that husband and wife are allowed to receive radd (return) since they are also receive reduction from their fixed shares in ' $a w l$ condition when the shares exceed the heritage. Furthermore, legal policy taken by Abdullah bin Mas'ud gave limitation to the heirs not entitled the reversion of radd. They are a son's daughter when she inherits with a daughter; a halfsister from father's line who inherits with a sister; and grandmother who inherits with other fixed heirs. ${ }^{13}$ Based on the provisions from those who support radd excluding husband and wife to receive the return, there are eight of the heirs who will receive it. They are; daughter, son's daughter, sister who has the same parents, sister from father's line, mother, grandmother (father's mother), sister from mother's line, and brother from mother's line. ${ }^{14}$ Father and grandfather though they are one of fixed share heirs they are excluded from radd system since they can also inherit as ashaba heirs. So, in the presence of father or gandfather the rest of heritage after being given to the fixed heirs will be taken by father or grandfather ${ }^{15}$.

\section{The provision of Radd in the Algerian Family Law}

Family laws' codification was undertaken by the Algerian Goverment several times after independence in 1962. However, it didn't come to pass because the Algeria's war of independence left the country with no political faction powerful enough to conduct

\footnotetext{
${ }^{10}$ Bayt al-mal (بيت المال) is an Arabic term that is translated as "House of money" or "House of Wealth." Historically, it was a financial institution responsible for the administration of taxes in Islamic states, particularly in the early Islamic Caliphate. It served as a royal treasury for the caliphs and sultans, managing personal finances and government expenditures. Further, it administered distributions of zakat revenues for public works

11 Mohamed Idir Mishnan, Printed Lecture in the Science of Inheritance for Fourth Year Students (Algeria: Faculty of Islamic Sciences, University of Algiers, 2004), 35.

${ }^{12}$ Ibn Qudamah, Al Mughni, vol. 4 (Beirut: Dar Ihya' al Turath al 'Araby, 1985), 296.

${ }^{13}$ Ibn Qudamah, 4:296.

${ }^{14}$ Maryam Ahmed Dagestani, Al-Mawarith fi al-Shari'ah al-Islamiah ala al-madhahib al-arba and its Application in the Egyptian Courts (Egypt, 2001), 71.

${ }^{15}$ Grandfather can only inherit in the absence of father.
} 
family law immediately. ${ }^{16}$ In 1980 the government proposed a draft code of family law. Then, after several years of discussion and deliberation, finally the goverment was able to codify it in June 1984. Its provisions were taken from various schools eventhough generally based on Maliki Schools but certain non Maliki schools, mostly Hanafi schools, were also incorporated. ${ }^{17}$ It's also taken from the Algerian draft code of Muslim law 1916 called Avant-project de code du droit Musluman Algerien and parallel legislation of some countries, mainly the neighbouring Morocco. ${ }^{18}$

The new family law code of Algeria is an enactment containing 224 articles applied to all Algerians. The Article number 167 of the Algerian Family Code states that If the the fixed share heirs don't takes all the heritage while the absence of ashaba heir/residuary, the rest will be given to the fixed share heirs according to their fixed share portions except couple. The rest of heritage can be given to one of the couple (husband or wife) if there is no ashaba heir or no one of the fixed share heirs or no one of uterine relatives (dzaw al Arham). It is the same as that of the Egyptian legislature in Article 30 of Personal Status Code. ${ }^{19}$ It is noted that the Algerian legislators had done intra-doctrinal reform ${ }^{20}$ as they combined the two opinions, where he took the opinion that returning the rest of heritage on the fixed share heirs except couple and the second opinion which is Returning the rest of heritage on one of the couple (husband or wife) in the absence of ashaba heir (aceb) or one of the fixed share heirs or one of uterine relatives (dzaw al Arham).

\section{The Radd Statuse in Algeria's Family}

Radd has 5 statuses, 21 and each has its own way to solve; The first case : the existence of one fixed share heirs without one of the couple -husband or wife-, so he takes all the money as fixed share or with radd effect. For example, a man died leaving one sister she takes all the money a half as fixed share and the rest half with radd effect. The second case: The existence of one multi type heirs or one fixed share heir without one of the couple -husband or wife-, they take money equally, and the denominator of this inheritance matter is their number as ashaba. E.g.; a) a man died leaving 3 daughters. They share all the heritage. One third as a fixed share and the rest with radd effect. b) a man died leaving 5 brothers from mother's line. They share the heritage One third as a fixed share and the rest with radd effect. c) a man died leaving grandmother and sister from mother's line. they have the same fixed share that is the sixth. Then the denominator of this inheritance matter is their number which is 2 so each of them take a half.

The third case: The existence of multi fixed share heirs without one of the couple (husband or wife), we find the number of shares less than the denominator. So we must abolish the first denominator. E.g.; a man died leaving mother and uterine sister.

\footnotetext{
${ }^{16}$ Engelcke, "Family Law Reform in Algeria," 308.

17 Tahir Mahmood, Family Law Reform in the Muslim World (New Delhi: The Indian Law Institute, 1972), 129.

18 Tahir Mahmood, Personal Law in Islamic Countries : History, Text and Comparative Analysis (New Delhi: Academy of Law and Religion, 1987), 17.

${ }^{19}$ Hassanein Mohamed Makhlouf, Al-Mawarith fi al-Shari'ah al-Islamiah (Egypt: Dar al Fadila, t.t.), 184.

${ }^{20}$ Mahmood, Family Law Reform in the Muslim World, 267.

${ }^{21}$ Mohamed Muslim, Mabahith fi Ilm al Mawarith, 5 ed. (Saudi Arabia: Dar al-Manara, 2004), 129.
} 
Table 1. Radd Calculation of The Third Case

\begin{tabular}{cccc}
\hline Order of heirs & Share & Ratio of share & Radd effect \\
\hline Mother & $1 / 3$ & $2 / 6$ & $2 / 3$ \\
\hline Uterine sister & $1 / 6$ & $1 / 6$ & $1 / 3$ \\
\hline
\end{tabular}

The denominator is 6 and the number of shares is 3 so less than the denominator then abolish the ex denominator and the number of shares which is 3 became the new denominator. The next example of this case is when a man died leaving sister full and Cosanguine Sister and Uterine Sister. The calculation is as follows:

Table 2. Radd Calculation of Another Case

\begin{tabular}{cccc}
\hline Order of heirs & Share & Ratio of share & Radd effect \\
\hline Sister Full & $1 / 2$ & $3 / 6$ & $3 / 5$ \\
\hline Cosanguine Sister & $1 / 3$ & $1 / 6$ & $1 / 5$ \\
\hline Uterine sister & $1 / 6$ & $1 / 6$ & $1 / 5$ \\
\hline
\end{tabular}

The denominator is 6 and the number of shares is 5 . So, the ex denominator is abolished and the number of shares which is 5 became the new denominator. The Fourth Case: The existence of fixed share heirs with one common fixed share with the existence of one from the couple (husband or wife). In this case, after we find that the inheritance matter has radd effect we solve it by putting the divisor of one of couple (husband or wife) as a denominator and his share becomes one share and the rest will be returned equally on all the others heirs. E.g.; a man died leaving wife and sister full.

Table 3. Radd Calculation of The Fourth Case

\begin{tabular}{cccc}
\hline Order of heirs & Share & Ratio of share & Radd effect \\
\hline Wife & $1 / 4$ & $1 / 4$ & $1 / 4$ \\
\hline Sister Full & $1 / 2$ & $2 / 4$ & The rest $3 / 4$ \\
\hline
\end{tabular}

This inheritance matter has radd effect. The denominator is the divisor of wife. The share of her is $1 / 4 \mathrm{viz} 1$. The rest for sister full with fixed share and the radd effect. Another example is when a man died leaving wife and 7 daughters. In this case, the calculations is as follows:

Table 4. Radd Calculation of The Other Case

\begin{tabular}{cccc}
\hline Order of heirs & Share & Ratio of share & Radd effect \\
\hline Wife & $1 / 8$ & $1 / 8$ & $1 / 8$ \\
\hline 7 daughters & $1 / 2$ & $4 / 8$ & The rest $7 / 8$ \\
\hline
\end{tabular}


The denominator is the divisor of wife: 8 . The share of her is $1 / 8$ viz 1 . The rest for the seven daughters with fixed share and the radd effect. The Fifth Case: The existence of multi fixed share heirs with one of the couple (husband or wife). After we make sure that this inheritance problem has the radd effect. Then, we solve it by using the following some steps. The first step is by putting the divisor of one of couple husband or wife - as a denominator and we give his/her right (which is one share because the denominator is the divisor of wife/ husband ) then we make the rest for all heirs in general without being detailed at first.

The second step is by eliminating the presence of one spouse and we solve it as if one couple doesn't exist. So, we'll find that the inheritance matter has the radd effect. We solve it as we did in the third step, and we return the denominator to the total ratio. The third step is determining the final denominator of inheritance matter. At this point, we compare the ratio of heirs in the first and second step either by symmetry or contrast to reach the final one. In the situation of symmetry, the final denominator is the divisor of spouse (wife or husband). The next we give one spouse his fixed share which is one share by considering the wife divisor as denominator itself. Then we give to heirs their shares which is the same as every heir has taken in second step with the radd effect as what he will take in the final summation. E.g., a man died leaving wife and mother and Uterine brother.

Table 5. Calculation of The Fifth Case

\begin{tabular}{cccc}
\hline Order of heirs & Share & Ratio of share & Radd effect \\
\hline wife & $1 / 4$ & $1 / 12$ & $1 / 4$ \\
\hline mother & $1 / 3$ & $4 / 12$ & $2 / 4$ \\
\hline Uterine brother & $1 / 6$ & $2 / 12$ & $1 / 4$ \\
\hline
\end{tabular}

The denominator in marital inheritance matter is the wife divisor. One share for her and the rest 3 for the other heirs in general without being detailed at first. The denominator in the inheritance matter with the radd effect is divisors $1 / 3$ and $1 / 6$. So, It's 6 returned to 3 due to radd effect. We observe that there is a similarity between the rest in marital inheritance matter (3) and the denominator in the inheritance matter with the radd effect (3). So the denominator in the final summation is the wife divisor (4) and her share in the final one is (1). The share of mother and brother from mother's line is the same as what they took in inheritance matter with the radd effect.

For situation of contrast: we can follow these steps; a) the final denominator is equal to the denominator of marital inheritance matter and then multiplied by the denominator of inheritance matter with the radd effect. b) the share of a spouse is equal to the final denominator divided by the divisor of the fixed share. $\mathrm{c}$ ) the share of heirs is equal to total of their shares in the final denominator column multiplied by the share of every heir in the radd effect column. E.g., when a man died leaving wife and sister full and uterine sister. 
Table 6. Calculation of The Case

\begin{tabular}{|c|c|c|c|c|}
\hline Order of heirs & Share & Ratio of share & Radd effect & $\begin{array}{l}\text { Final denominator } \\
4 \times 4=16\end{array}$ \\
\hline wife & $1 / 4$ & $3 / 12$ & $1 / 4$ & $4 / 16$ \\
\hline Sister full & $1 / 2$ & $6 / 12$ & \multirow{2}{*}{3} & $9 / 16$ \\
\hline Uterine sister & $1 / 6$ & $2 / 12$ & & $3 / 16$ \\
\hline
\end{tabular}

The denominator of the marital column is the wife divisor (4). So, one share is for her and the rest (3) for the other heirs in general without being detailed at first. The denominator radd effect column is taken from the divisors $1 / 2$ and $1 / 6$. So, it's 6 returned to 4 due to radd effect. We observe that there is a contrast between the rest in Marital inheritance matter (3) and the denominator in the inheritance matter with the radd effect (4). Then, the explanation of the final summation in the final denominator column is as follows: a) The final denominator (16) is equal to the denominator of Marital inheritance matter(4) multiplied by the denominator of inheritance matter with the Radd effect (4). b) The wife share is equal to the final denominator (16) divided by the divisor of her fixed share(4) equals to 4 shares. c) The sister full share equals to the rest in marital column (3) multiplied by his share in the radd effect column (3) equals to 9 shares. d) The share of uterine sister is equal to the rest in marital one(3) multiplied by his share in the radd effect one (1) equals to 3 shares.

\section{Conclusion}

In Islamic Jurisprudence, there are two main doctrines regarding $\mathrm{radd} / \mathrm{return}$. One opposes the concept by giving the return to bayt al-maal as mulims representatives and noot to the heirs. It's the opinion stated by Zayd ibn Thabit, Imam Malik and Shafei, AlAuza'I, Daoud Al Dhahiri. The other doctrine is stated by Omar, Ali, ibn 'Abbas, Abdullah bin Mas'ud, the doctrine of Imam Ahmad, Abu Hanifa and their companions, the adherents of Maaliki school and Shaafe'i school who support radd. According to them, in case of no ashaba heir, the return is given to the fixed heirs excluding wife and husband. In the Algerian Family lay law the two opinions are combined in which the algerian legislator takes the opinion that returning the rest of heritage on the fixed share heirs except couples and then gives condition for them to benefit the return if the deceased leaves no ashaba heir (aceb), anyone of the fixed share heirs or any uterine relatives (dzaw al Arham).

\section{Reference}

Al Shabuni, Muhammad Ali. Al-Mawarith fi al-Shari'ah al-Islamiah fi Daw'i alKitabwa al-Sunnah. Egypt: Dar al-Hadith, t.t.

Dagestani, Maryam Ahmed. Al-Mawarith fi al-Shari'ah al-Islamiah ala al-madhahib al-arba and its Application in the Egyptian Courts. Egypt, 2001.

Engelcke, Dörthe. "Family Law Reform in Algeria: National Politics, Key Actors, and Transnational Factors." Dalam Women and Social Change in North Africa, disunting oleh Doris H. Gray dan Nadia Sonneveld, 1 ed., 308-30. Cambridge University Press, 2018. https://doi.org/10.1017/9781108303415.015. 
Fyzee, Asaf A. A. Outlines Of Muhammadan Law. 3 ed. New Delhi: Oxford University Press, 1948.

Ibn Qudamah. Al Mughni. Vol. 4. Beirut: Dar Ihya' al Turath al 'Araby, 1985.

Khan, Issa, Md. Faruk Abdullah, Noor Naemah Abdul Rahman, Mohd Roslan Bin Mohd Nor, dan Mohd Yakub Zulkifli Bin Mohd Yusoff. "The right of women in property sharing in Bangladesh: Can the islamic inheritance system eliminate discrimination?" SpringerPlus 5, no. 1 (3 Oktober 2016). https://doi.org/10.1186/s40064-016-3347-2.

Mahmood, Tahir. Family Law Reform in the Muslim World. New Delhi: The Indian Law Institute, 1972.

. Personal Law in Islamic Countries: History, Text and Comparative Analysis. New Delhi: Academy of Law and Religion, 1987.

Makhlouf, Hassanein Mohamed. Al-Mawarith fi al-Shari'ah al-Islamiah. Egypt: Dar al Fadila, t.t.

Mishnan, Mohamed Idir. Printed Lecture in the Science of Inheritance for Fourth Year Students. Algeria: Faculty of Islamic Sciences, University of Algiers, 2004.

Muslim, Mohamed. Mabahith fi Ilm al Mawarith. 5 ed. Saudi Arabia: Dar al-Manara, 2004.

Qazwiny, Aby Abdillah Muhammad bin Yazid al. Sunan Ibn Majah. Riyadh: Maktabah al Ma'arif li al Nasyr wa al Tawzi', t.t.

Sajastany, Abi Dawud Sulaiman bin al asy'ath al. Sunan Aby Dawud. Riyadh: Maktabah al Ma'arif li al Nasyr wa al Tawzi', t.t.

Zuhaily, Wahbah al-. Al fiqh al islami wa adillatuh. Vol. 10. Beirut: Dar al-Fikr, 2006. 